\title{
Afrikaans as an index of identity among Western Cape Coloured communities
}

\author{
Alfred Mautsane Thutloa \& Kate Huddlestone \\ Department of General Linguistics, Stellenbosch University, Private Bag X1, Matieland, 7602, South Africa \\ E-mail: thutloa_am@hotmail.com; katevg@sun.ac.za
}

\begin{abstract}
In South Africa, reports on language shift have focused on instances of language shift from indigenous African languages to English. There is, however, also research that suggests that language shift is taking place from Afrikaans to English in the Western Cape. Anthonissen (2009), for example, notes in her research among Coloured communities that a shift has taken place from Afrikaans first language (L1), across three generations, to English L1. Against this backdrop, this paper investigates language shift in two semi-urban Western Cape Coloured communities; in particular, it examines what patterns of language shift/maintenance can be observed, and investigates sociolinguistic factors, such as age, language of schooling, socio-economic status and language attitudes, to which the observed patterns can be ascribed. The aim is to ascertain whether language shift, from Afrikaans to English has taken place, and which factors appear to encourage or discourage language shift in the two communities. Through the administration of a questionnaire to 50 households, 25 in each of the communities, the study this paper reports on examined language use across a number of domains: at home, in the community, in church, and in the workplace. It also explored the language attitudes of the participants (53 in total) towards Afrikaans in order to investigate the possibility that this language might be used for indexing their identity. The collected data does not provide any evidence of language shift from Afrikaans to English. However, there seems to be increased use of English in the public domains (such as the workplace and in the church), with Afrikaans being used almost exclusively in the intimate domains. It appears that Afrikaans remains a strong marker of identity in the two semi-urban Western Cape Coloured communities, despite English largely being regarded as the language of upward socioeconomic mobility.
\end{abstract}

Keywords: language shift, language maintenance, language attitudes, bilingualism

\section{Introduction}

The study reported on in this paper set out to investigate whether language shift is taking place from Afrikaans first language (L1) to English L1, a language often associated with social mobility and work opportunities, in two specific historically Afrikaans Western Cape "Coloured" communities that fall outside of the Cape Metropolitan area.

\footnotetext{
${ }^{1}$ Adhikari (2005:2) points out that in South Africa, "contrary to international usage, the term 'Coloured' does not refer to black people in general". Rather, the term is used as a label for a varied social group with diverse cultural and geographic origins. According to Hendricks (2005), "Coloureds are often identified as South Africans who are of mixed race; [they] are descendants of the sexual liaisons between colonialists, slaves and the indigenous Khoisan". This is not a particularly accurate definition, as many slaves of Malaysian descent,
} 
Language shift has been observed in a number of contexts and also defined in a number of different ways. In the words of Fishman (1964:32), "[t]he study of language maintenance and language shift is concerned with the relationship between change or stability in habitual language use, on the one hand, and ongoing psychological, social or cultural processes, on the other hand, when populations differing in language are in contact with each other". Language shift can be defined as "the replacement of one language by another as the primary means of communication and socialisation within a community" (Mesthrie, Swann, Deumert and Leap 2000:253). Myers-Scotton (2006:90) points out that are various societal, in-group and individual factors central to language maintenance, the opposite of language shift. These factors include demographic factors - whether large numbers of speakers live together; occupational factors - whether speakers of the same language work together, with restrictive socio-economic mobility; educational factors - whether speakers have access to L1 education; social networks and group attitudes about the L1 as an ethnic symbol; and psychological attachment to the L1 for self-identity.

In a multilingual country, such as South Africa, where most citizens are proficient in more than one language, language shift is a complex phenomenon to study. Reports on the phenomenon of language shift in South Africa have generally focused on the marginalisation of indigenous African languages in favour of English (cf. Bekker 2005; De Klerk 2006; Kamwangamalu 2007, 2008). This is not surprising given the country's previous political dispensation that promoted only English and Afrikaans as official languages. With the advent of a new political order in 1994, the promotion of previously marginalised languages became a national concern, hence the promotion and preservation of these languages is vested in the new constitution. According to the Constitution of the Republic of South Africa Act, No. 108 of 1996:

Recognising the historically diminished use and status of the indigenous languages of our people, the state must take practical and positive measures to elevate the status and advance the use of these languages.

There is evidence that the large-scale shift from indigenous African languages to English (cf. Kamwangamalu 2007) is also evident in certain historically Afrikaans communities. Specifically, the phenomenon of language shift from Afrikaans to English in certain Western Cape Coloured communities has formed the focus of a number of studies, namely Anthonie (2009); Anthonissen (2009); Anthonissen and George (2003); Dyers (2008); and Farmer (2008). Anthonissen (2009), for example, notes that various indicators of language shift are present in the data collected from middle-class Coloured families, specifically that there is a difference across generations of what participants identify as their own L1; there is a shift in the language of schooling from Afrikaans to English L1; and church services, an important form of identity for these communities, show a shift from being conducted mainly in Afrikaans to services that include both English and Afrikaans, and in some cases, services conducted solely in English. Dyers (2008), in turn, argues that despite the shift from Afrikaans L1 to English L1 reported by, for example, Anthonissen (2009), most Coloured people in the Western Cape maintain their L1 Afrikaans, and that "the language remains a key component of their ethnolinguistic identity" (Dyers 2008:52).

particularly a part of the Muslim community, are descendants of slaves, but actually not of 'mixed race' in the sense given by Hendricks. Furthermore, the term "Coloureds" is tainted in that, due to its former use in racial classification, it has negative connotations so that many object to its use. The term is still used for lack of any more acceptable alternatives, and, following Adhikari (2005), is spelled with a capital " $\mathrm{C}$ ". 
This paper aims to contribute to the established literature by providing further data on, and insight into, the phenomenon of language shift from Afrikaans to English in the Western Cape, as well as to contribute to the scholarly reflection on concepts and processes involved in language shift.

Against this background, the study reported here set out to address the following research questions:

(i) What are the patterns of language shift/maintenance in the two semi-urban Western Cape Coloured communities?

(ii) Which sociolinguistic factors - specifically age, language of schooling, socioeconomic status, and language attitudes - appear to encourage or discourage language shift in the two Western Cape Coloured communities?

The paper is organised as follows: section 2 provides a description of the two communities in which the study reported on was undertaken; section 3 outlines the research methodology, providing a description of the participants, the research instrument, and the process of data collection; section 4 reports the results of the data collection, while section 5 provides a brief discussion and concluding remarks.

\section{The context of the study}

Community 1 was established as a settlement for Coloureds in 1901 and gained protection as a heritage site in 1976. According to Pistorius and Todeschini (2004:68) this community can be characterized as "an exemplar of the patterns and processes of colonial adaptation and development that have formed the Cape Winelands landscape that we know today". Community 2, on the other hand, was specifically laid out by the apartheid government to become a Coloured area in the 1970s (Brink 2006:23). According to Deumert (2005:130), Coloured ethnicity is "extremely heterogeneous, including not only the descendants of the ethnically diverse slave population, but also the indigenous Khoe as well as everyone who could not be classified unambiguously as being either black (African) or white". Dyers (2004:24) further points out that Coloured people "have adopted a largely Westernised lifestyle, and have maintained few, if any, of the cultural practices of the past".

According to the Stellenbosch Transformation Research Project (2003:21-22), community 1 occupies a smaller geographical area and has a higher density of inhabitants (9,460 residents) in contrast to community 2 (6,249 residents). From a geographic perspective (in terms of scale), community 2 seems larger, but it is actually a smaller area as other smaller communities are integrated into this area. Both of these communities are in close proximity to the town of Stellenbosch, where the Afrikaans language is still a dominant language of power. With regards to schooling, there are three primary schools in community 1 , of which only one provides bilingual Afrikaans/English education. The single high school and the other two primary schools are all Afrikaans medium. In community 2 all three primary schools and the high school are Afrikaans medium. The average age in both community 1 and community 2 is between 30 and 39 years old (Stellenbosch Transformation Research Project 2003:12). The median age of the participants in the study reported on in this paper was 42 ; the youngest participant was 15 and the oldest 88 . 
In the present study the information used to determine socio-economic status for the whole area was taken from the Stellenbosch Transformation Research Project (2003). There were no direct questions related to socio-economic status in the questionnaire, for reasons related to ethical clearance considerations. This meant that the socio-economic status of the participants could only be limitedly corroborated by the questionnaire. Instead the researcher made use of other, less quantifiable, indicators, such as the observation of how many additional (informal) dwellings were present on a single plot. The data provided by the Stellenbosch Transformation Research Project (2003) was in turn supplemented by the Human Sciences Research Council (HSRC) household summary matrix, given in Appendix A.

The HSRC matrix is significant for this study as it offers a framework in which to understand the socio-economic status of the two communities. This matrix is based on quantifiable models of socio-economic standing developed by looking at the variables of: education, income, unemployment, and density per household. These variables offer reliable insight into the socio-economic status of a number of communities. According to the HSRC matrix, the communities - community 1 and community 2 - fall into Group A, into two (Bare Basics and Rainbow Basics) of the three subgroups. The first group is characterised by young Africans or Coloureds with low income, low levels of education, high unemployment, and a predominantly female population. The second group is linked to young Africans, Coloureds or Asians, with medium levels of education, standard (average) levels of income, high unemployment and a high incidence of females. This correlates with the results of the data collection (reported on in section 4) which show that both communities consist of mainly Coloureds with low or medium levels of education and with standard levels of income and a predominantly female population. There is no significant difference in socio-economic status between community 1 and community 2 .

\section{Research methodology}

Fifty households were approached for this study, twenty-five in each community, with the aim of soliciting at least one participant in each household, either a grandparent (65+), parent $(35+)$, or child/adult dependant $(15-25+)^{2}$. The research instrument utilised in the data collection, a questionnaire given in Appendix B, was completed for each participant. In total the data collected included 53 completed questionnaires. Each questionnaire was administered by the primary researcher who assisted respondents with filling in details, except in two cases (in community 1) where the participants preferred to complete the questionnaire themselves. To determine patterns of language shift/maintenance and which sociolinguistic aspects these patterns can be ascribed to, the English/Afrikaans questionnaire was used to address the following questions:

- which language the participants (and their grandparents/parents/children) regard as their L1;

- which language/s they use across various domains (at home, in the community, in church, and in the workplace);

- which language(s), Afrikaans and/or English, each generation has/had as their language of schooling;

\footnotetext{
${ }^{2}$ The study by Anthonissen (2009) investigated language shift (from Afrikaans L1 to English L1) among participants in the age group $10-60+$ (children $10-23+$, parents aged 35+, and grandparents $60+$ ). In this study, the target age for children had to be increased to $15-25+$ for ethical clearance purposes.
} 
- which language they prefer (or would prefer) as their and their child/children's language of schooling;

- whether they attach any value to knowing more than one language; and

- whether they have difficulty in using more than one language at different times.

As mentioned in section 2, no direct questions were asked regarding socio-economic status, instead, the English/Afrikaans questionnaire was structured in a manner which allowed us to determine the approximate socio-economic status of participants. The ratio of employed versus unemployed members per household, as well as their level of education were taken as indicators of the participants' socio-economic status and the available census data on both communities were also consulted. The questionnaire was also designed to elicit statements related to language attitudes, defined as "attitudes that speakers of different languages or varieties of a language have towards each others' languages or their own" (Richards and Schmidt 2002: 286), in order to determine the feelings that participants have about Afrikaans and English in the two communities.

Data was collected in community 1 and community 2 on alternate days, over a period of one week. To ensure that the target of 50 households was reached, the process of random sampling was followed. Random sampling is a sampling technique where a group of participants are selected from a general group, each participant is chosen completely by chance, and each member of the population (larger group) has a chance (non-equal) of being selected (Easton and McColl 1997). Between two and three households were selected in each of the ten or so streets from which houses were sampled in community 1 and community 2 . Maps were sourced from Google to assist in navigating through both communities. Not all streets could be included, as the researchers wished to ensure that the 25 questionnaires completed in each area were as representative as possible of the overall community. Due to low statistical representivity, however, the findings are not presented as generalizable claims.

\section{Results of the data collection}

This section reports on the results of the data collection with particular attention to evidence of language shift or maintenance and the effect of sociolinguistic factors that were observed in the two semi-urban Western Cape communities. The key observations on the evidence of language shift or maintenance will be discussed in section 4.1, while the relevant sociolinguistic factors will be elaborated on in section 4.2.

\subsection{Evidence of language shift or maintenance}

The data collected in community 1 and community 2 comprised 53 participants in total, with generation 1 participants (age group 65 - 88) forming $18 \%$ of the sample, generation 2 participants (age $35-63$ ) forming the largest group at 55\% of the sample, and generation 3 (age group $15-32$ ) comprising $27 \%$ of the total sample.

The general trends that were noted from the data are the following:

- $100 \%$ of the participants regarded Afrikaans as their L1;

- $98 \%$ of the participants indicated that they have the same L1 as their parents, namely Afrikaans. $100 \%$ of the generation 3 participants regard Afrikaans as their L1. These are participants who have the same L1 as their generation 2 parents, clearly showing 
that there has not been a shift from Afrikaans L1 to English L1, from generation 2 to generation 3. Additionally, $96 \%$ of the generation 1 participants indicated that they also have the same L1 as their generation 2 children, further showing that there was no general language shift from generation 1 to generation 2 in this study.

- Data collected for this study indicated that Afrikaans is the language used by participants across all domains: in close family interactions, with a partner, with children, with parents, in the community, in church, and in the workplace. $98 \%$ of the participants use Afrikaans in close family interactions; $91 \%$ use Afrikaans with their partner; 74\% speak only Afrikaans with their children; 91\% use Afrikaans when speaking to their parents; $94 \%$ of participants use Afrikaans when they speak to people in the community; $87 \%$ of participants attend church services where Afrikaans is the language used, with $40 \%$ of church sermons being conducted in both English and Afrikaans; and $58 \%$ of participants use only Afrikaans in the workplace.

It follows from these trends that there is no clear evidence of language shift, from Afrikaans to English, in the two communities. Even increased use of English in the domains of work and the church are evidence of the need for interlocutors to speak and interact across multilingual contexts, while maintaining their L1, rather than evidence of a potential language shift.

\subsection{Sociolinguistic factors}

This section reports on the results of the data collection with respect to a number of sociolinguistic aspects, namely age, language of schooling, socio-economic status, and language attitudes.

As all the participants, even young participants, specified that Afrikaans is their first language, one way to evaluate age as a factor was to link it to language of schooling. This follows from research that has shown that in instances where the language of schooling is different from the home language, this can encourage language shift from the home language to the language of schooling (Farmer 2008; Anthonissen 2009).

In terms of language of schooling, the patterns of language use were the following:

- The majority (91\%) of participants have/had Afrikaans as their medium of instruction in school. However $53 \%$ of participants noted a preference for bilingual education for their children (Afrikaans and English), and 40\% would prefer English as the medium of instruction for their children's schooling.

- Among generation 3 participants, 98\% of them indicated that Afrikaans is their language of schooling, which is the same language in which their generation 2 parents were schooled.

Based on this data, there is no evidence for language shift among participants regarding the language of schooling in this study. As pointed out in section 2, all but one of the schools in these communities are Afrikaans medium, however, if bilingual or monolingual English education were available for participants' children, it is possible that the patterns of language use observed above would change. As discussed in section 1, age and language of schooling can impact on the process of language shift, as individuals who are traditionally Afrikaans speaking adopt English as an additional language in school, and eventually shift completely to English. 
Regarding socio-economic status, no direct questions were asked in this regard; however during the data collection process, it was observed that community 1 appeared slightly more affluent than community 2 . The former had mostly free standing homes with a yard, whereas the latter comprised smaller houses, often Wendy houses or informal settlement type households. This observation is supported by the Stellenbosch Transformation Research Project (2003) which notes that community 2 has a higher percentage of informal dwellings than community 1 . However, as noted in section 2, both communities have a relatively low socio-economic status. Kamwangamalu (2007) has mentioned in his research that language shift from indigenous African languages to English is largely due to the need for upward social mobility through better work opportunities. Taking this into consideration, traditionally Afrikaans communities, such as those in this study, might be expected to regard English as a way to improve their employment opportunities. However, given that, in the geographic area in which these two communities are situated, Afrikaans is still a language of power, the economic opportunities offered by English are not necessarily greater than those offered by Afrikaans.

Many of the participants seemed to recognise the value of speaking English for better work opportunities, despite the fact that they still rated Afrikaans as an important marker of their identity, with the comment that they, and their children, were Afrikaans gebore ("born Afrikaans"), expressed by at least five of the participants. Of course, low levels of education, characteristic of the participants from community 2, and to a lesser extent of those from community 1, restricts socio-economic mobility, which, as Myers-Scotton (2007) observes, encourages language maintenance.

In this study, language attitudes involved feelings expressed about Afrikaans and English. Two questions in the questionnaire were specifically designed to gauge participants' language attitudes, namely:

(i) Do you find it valuable to know more than one language?

(ii) Do you find it difficult to use different languages at different times?

Only three participants in the study did not agree with the statement that it is valuable to know more than one language. The reasons for their choice did not show a preference for either English or Afrikaans, as indicated by the utterances in (1), produced by participant 4, a 71 year old female from community 1, referring to the importance of knowing more than one language, and (2), as a response to the question about finding it difficult to use different languages at different times:

\section{Op my ouderdom dis nie belangrik nie.}

"At my age it's not important."

Dis moelik om my ouderdom Engels te leer.

"It's difficult at my age to learn English."

In community 2, participant 42 , a 28 year old female, stated that she does not find it valuable to know more than one language. Despite this, she does not use only Afrikaans across all domains. She uses both Afrikaans and English in close family interactions, and indicated that she would have preferred English as her language of schooling because she feels it would 
have made it easier for her to communicate with other people that are not Afrikaans. Her attitude towards both Afrikaans and English shows a clear need to be more proficient and competent in speaking English. Although she admitted that the whole community is Afrikaans (almal is Afrikaans), she understands that not having command of another language, i.e. English, can be limiting:

Meeste van ons is almal Afrikaans, some people verstaan nie Afrikaans nie. "Most of us are Afrikaans, some people don't understand Afrikaans."

She also stated that:

As jy Afrikaans praat, moet jy dit leer.

"If you speak Afrikaans you must learn it." [referring to the English language, that people should learn to speak the language even when they are Afrikaans speaking]

Across the study several comments expressed a strong sense of Afrikaans being an important aspect of the participants' identity. In this respect, the most common statements were that they (the participants) were born Afrikaans and that the community they live in is Afrikaans. There were two distinctive patterns of language attitudes that were evident among participants group 1 had Afrikaans as an L1 and were the least proficient in English, while group 2 also had Afrikaans as an L1, but showed a strong bilingual identity. Most of the participants belonged to group 2 (94\%). They expressed how English offered them access to communicate with different interlocutors in at least one of the less intimate domains, i.e. at the workplace or church.

The attitudes of the few individuals characterised as group 1 are evident in the data from participant 24, a 40 year old female who said:

\section{Ek het nie ander tale geleer nie.}

"I did not learn other languages."

As a response to question (ii) above, participant 24 further added that:

$$
\begin{aligned}
& \text { Ek ken nie ander tale nie. } \\
& \text { "I don't know other languages." }
\end{aligned}
$$

Despite the acknowledgement of the importance of English by the majority of participants, it would appear that Afrikaans remains a strong index of identity in these two communities. These findings are consistent with research by Dyers $(2007,2008)$ on the significance of vernacular Afrikaans in working class Coloured communities. As she points out

even in the presence of a powerful language of wider communication, people can continue to identify powerfully with their home languages, especially when it enhances their personal and group identities or is a marker of their ethnolinguistic distinctiveness (Dyers 2007:97).

As expected from bilingual communities, the data collected also showed incidences of code switching/mixing, defined as "the alternate use of two languages within the same utterance or during the same conversation" (Hoffmann 1991: 110). As code switching was not the focus of 
this research, the participants' use of more than one language in a conversation was observed through the lens of bilingualism and language shift. The assumption being that extensive code switching in participants' speech could signal a move to a more bilingual identity, and serve as a starting point for eventual language shift. Typical examples of code switching observed in the two communities included the following:

$$
\begin{aligned}
& \text { Meeste van ons is almal Afrikaans, some people verstaan nie Afrikaans nie. } \\
& \text { "Most of us are Afrikaans, some people don't understand Afrikaans." }
\end{aligned}
$$

Dit gee vir jou ' $n$ chance met verskillende kulture te komunikeer.

"It gives you a chance with different cultures to communicate."

Ek vind dit nie moelik nie, ek is op ' $n$ level of being fully bilingual in English en Afrikaans. "I don't find it difficult, I am on a level of being fully bilingual in English and Afrikaans."

Ek is well gifted met tale, Engels en Afrikaans, ek het familie wat hulle huistaal Engels is. "I am well gifted with languages, English and Afrikaans, I have family whose home language is English."

Generally, however, most participants did not code-switch when they responded to the questionnaire. The participants responded mostly in Afrikaans without using English words, and where the participants responded in English, they also used English throughout the duration of the questionnaire. What can be deduced from this is that although participants in community 1 and community 2 may strive to be more bilingual in English and Afrikaans, they generally speak Afrikaans without mixing both languages during a conversation, at least to the extent observed by the primary researcher.

\section{Concluding remarks}

This paper reported on a study of language shift in two specific, semi-urban, Western Cape Coloured communities. In particular, the study investigated the patterns of language shift/maintenance as well as sociolinguistic factors to which these patterns can be ascribed, i.e. age, language of schooling, socio-economic status, and language attitudes. As noted, qualitative studies by Anthonissen and George (2003) and Anthonissen (2009) provide evidence of language shift among certain traditionally Afrikaans L1 Western Cape communities (across three generations) from Afrikaans L1 to English L1. However, in the data collected for this study, there was no clear evidence of language shift from Afrikaans L1 to English L1, even among participants who regarded English as the language of social mobility and a language that would offer their children better work opportunities.

The results of the data collection clearly show the transfer of Afrikaans from one generation to the next. What can be said for these two communities is that the Afrikaans language is valued across all domains. As the studies by Anthonissen and George (2003) and Anthonissen (2009) are quite convincing in showing that there is language shift among traditionally Afrikaans L1 communities to English L1, it should be noted that these studies were conducted in communities located in the Cape Metropolitan area. One can speculate that either the process of language shift is localised in or around the Cape Metropolitan, or that the two semi-urban communities discussed in the present study have not been greatly affected by such 
a shift. Anthonissen (2009) notes that the language shift observed is occurring in middle class Coloured communities. In this study, however, the participants were all working class, living in fairly closed communities. The lack of language shift in these communities therefore correlates with evidence that language shift is a phenomenon more prevalent among middle class communities (Anthonissen 2009; Kamwangamalu 2007).

Furthermore, the nature of the two communities, and the attitudes towards Afrikaans expressed by the participants, correlate with Myers-Scotton's (2006:90) various societal, ingroup and individual factors favouring language maintenance, mentioned in section 1. Both communities are dominated by large numbers of Afrikaans speakers living together; participants work together with speakers of Afrikaans; members of both communities have restrictive socio-economic mobility; members of both communities have access to Afrikaans L1 education; participants from both communities seem to share group attitudes about Afrikaans as an ethnic symbol; and most of the participants in the study exhibit psychological attachment to Afrikaans for self-identity.

The data presented in this thesis support the observation that the phenomenon of language shift is a varied and dynamic one that is different for different communities (Myers-Scotton 2007). While the prestige and socio-economic mobility attached to the English language is a factor which could inspire language shift, in the communities investigated in this study it appears that the community's own sense of self and cultural and/or linguistic identification acts as a buffer against a new language, regardless of the economic benefits associated with the new language. Afrikaans remains an index of identity for these two specific Western Cape Coloured communities.

\section{Acknowledgements}

This paper is based on a Masters thesis, Thutloa (2010), completed under the supervision of Dr Kate Huddlestone.

\section{References}

Adhikari, M. 2005. Not white enough, not black enough: Racial identity in the South African Coloured community. Athens: Ohio University Press.

Anthonissen, C. 2009. Bilingualism and language shift in Western Cape communities. Stellenbosch Papers in Linguistics PLUS 38: 1-23.

Appel, R. and P. Muysken. 2006. Language contact and bilingualism. Amsterdam: Amsterdam University Press.

Bekker, I. 2005. Language attitudes and ethnolinguistic identity in South Africa: A critical review. In J. Cohen, K. McAlister, K. Rolstad and J. MacSwan (eds). Proceedings of the 4th International Symposium on Bilingualism. Somerville, MA: Cascadilla Press, 233-239.

Brink, C. 2006. No lesser place: The taaldebat at Stellenbosch. Stellenbosch: Sun Press.

De Klerk, V. 2006. Codeswitching, borrowing and mixing in a corpus of Xhosa English. The International Journal of Bilingual Education and Bilingualism 9(5): 597-614.

De Klerk, V. and B. Bosch. 1998. Afrikaans to English: A case study of language shift. South African Journal of Linguistics 16(2): 43-50. 
Dyers, C. 2007. An investigation into the role of the Afrikaans language in indexing the individual and collective self among some township youth in South Africa. Journal of International Social Research 1(1): 83-101.

Dyers, C. 2008. Language shift or maintenance? Factors determining the use of Afrikaans among some township youth in South Africa. Stellenbosch Papers in Linguistics 38: 49-72.

Easton, V.J. and J.H. McColl. 1997. Statistics Glossary v1.1. Available online: http://www.stats.gla.ac.uk/steps/glossary/index.html (Accessed 20 May 2010).

Farmer, J.L. 2008. Language choices of English L1 learners in a Western Cape high school. Master's thesis, Stellenbosch University.

Fasold, R. 1984. The sociolinguistics of society. Oxford: Basil Blackwell.

Fishman, J.A. 1964. Language maintenance and language shift as a field of inquiry: A definition of the field and suggestions for its further development. Linguistics 2(9): 3270.

Gough, D.H. 1996. English in South Africa. In P. Silva, W. Dore, D. Mantzel, C. Muller and M. Wright (eds). A dictionary of South African English on historical principle. Oxford: Oxford University Press.

Hendricks, C. 2005. Debating Coloured identity in the Western Cape. Institute for Security Studies. African Security Review 14(4): 117-119.

Hoffman, C. 1991. An Introduction to Bilingualism. London: Longman

Kamwangamalu, N.M. 2007. One language, multi-layered identities: English in a society in transition, South Africa. Oxford: Blackwell Publishing.

Kamwangamalu, N.M. 2008. From linguistic apartheid to linguistic co-habitation: code switching in print advertising in post-apartheid South Africa. Journal of Creative Communications 3(1): 99-113.

Mesthrie, R., J. Swann, A. Deumert and W.L. Leap. (eds). 2000. Introducing sociolinguistics. Edinburgh: Edinburgh University Press.

Mugaddam, A.R.H. 2006. Language maintenance and shift in Sudan: The case of migrant ethnic groups in Khartoum. International Journal of the Sociology of Language 181: 123-136.

Myers-Scotton, C. 2006. Multiple voices: An introduction to bilingualism. Oxford: WileyBlackwell.

Omoniyi, T. and J.A. Fishman. 2006. Explorations in the sociology of language and religion: Discourse approaches to politics, society and culture. Amsterdam: John Benjamin.

Richards, J.C. and R.W. Schmidt. 2002. Longman Dictionary of Language Teaching and Applied Linguistics. $3^{\text {rd }}$ Edition. Harlow: Longman

Thutloa, A.M. 2010. Investigating language shift in two semi-urban Western Cape communities. Master's thesis, Stellenbosch University. 


\section{Appendix A - HSRC household summary matrix}

\begin{tabular}{|c|c|c|}
\hline Cluster & Subcluster & HSRC Segment \\
\hline \multirow{13}{*}{$\begin{array}{l}\text { Cluster A } \\
\text { Predominantly high density } \\
\text { population composed of non white } \\
\text { households, of mainly } 4 \text { to } 6 \\
\text { people. } \\
\text { Most individuals with low to } \\
\text { medium education level, as well as } \\
\text { low to medium income per capita. }\end{array}$} & \multirow{5}{*}{$\begin{array}{l}\text { A1: Bare Basics } \\
\text { Young Africans or Coloureds with quite low education, } \\
\text { low income, high unemployment, and a high proportion } \\
\text { of females. } \\
\text { High density rural areas, with many traditional dwellings. } \\
\text { On average households composed of } 6 \text { persons. }\end{array}$} & $\begin{array}{l}\text { Mpumalanga } \\
(\mathrm{n}=57 \text { 774) }\end{array}$ \\
\hline & & $\begin{array}{ll}\text { Eastern } & \text { Nkosi } \\
(n=297671) & \end{array}$ \\
\hline & & $\begin{array}{l}\text { Ugogo } \\
(\mathrm{n}=244737)\end{array}$ \\
\hline & & $\begin{array}{l}\text { Farmlands } \\
(\mathrm{n}=801066)\end{array}$ \\
\hline & & $\begin{array}{l}\text { Merino } \\
(\mathrm{n}=602 \text { 171) }\end{array}$ \\
\hline & \multirow{6}{*}{$\begin{array}{l}\text { A2: Rainbow Basics } \\
\text { Young Africans, Coloureds or Asians, most with medium } \\
\text { education, average income per capita, high proportion of } \\
\text { people not working, and a high incidence of females. } \\
\text { Predominantly households of } 4 \text { people living in half paid } \\
\text { or rented western houses, located in urban areas. }\end{array}$} & $\begin{array}{l}\text { African Ngani } \\
(\mathrm{n}=378 \text { 428) }\end{array}$ \\
\hline & & $\begin{array}{l}\text { Mjondolas } \\
(\mathrm{n}=816226)\end{array}$ \\
\hline & & $\begin{array}{l}\text { Periphery } \\
(n=196609)\end{array}$ \\
\hline & & $\begin{array}{l}\text { South Western } \\
(\mathrm{n}=212724)\end{array}$ \\
\hline & & $\begin{array}{l}\text { Rainbow Crescent } \\
(\mathrm{n}=610838)\end{array}$ \\
\hline & & $\begin{array}{l}\text { Eastern Mosaic } \\
(\mathrm{n}=416 \text { 136) }\end{array}$ \\
\hline & \multirow{2}{*}{$\begin{array}{l}\text { A3: Amadoda } \\
\text { Young to middle-age Africans with medium education, } \\
\text { low to medium income per capita, low unemployment, } \\
\text { and a high proportion of males. } \\
\text { Households of mainly } 6 \text { people located in urban areas. }\end{array}$} & $\begin{array}{ll}\begin{array}{l}\text { Miners } \\
(n=157 ~ 129)\end{array} & \text { Glory } \\
\end{array}$ \\
\hline & & $\begin{array}{l}\text { Yokels } \\
(\mathrm{n}=788587)\end{array}$ \\
\hline \multirow{6}{*}{$\begin{array}{l}\text { Cluster B } \\
\text { High incidence of white individuals } \\
\text { living predominantly in households } \\
\text { of } 1 \text { to } 4 \text { persons. } \\
\text { Most individuals with medium to } \\
\text { high income as well as medium to } \\
\text { high education level. }\end{array}$} & \multirow{2}{*}{$\begin{array}{l}\text { B1: Got It Good } \\
\text { Medium to high household income, people living in } \\
\text { hostel or flats type dwelling situated in urban areas. Small } \\
\text { households of } 1-3 \text { persons. } \\
\text { Mainly young, English speaking individuals with medium } \\
\text { to high education, and low unemployment level. }\end{array}$} & $\begin{array}{l}\text { Golden } \\
(\mathrm{n}=484 \text { 872) }\end{array}$ \\
\hline & & $\begin{array}{l}\text { Skyscrapers } \\
(n=203265)\end{array}$ \\
\hline & \multirow{2}{*}{$\begin{array}{l}\text { B2: Lekker Lywe } \\
\text { Young Afrikaans speaking individuals, many with } \\
\text { medium education level, and quite high income. } \\
\text { On average small households composed of } 1 \text { to } 2 \text { people. }\end{array}$} & $\begin{array}{l}\text { Hostelry } \\
(n=172144)\end{array}$ \\
\hline & & $\begin{array}{l}\text { Holdings } \\
(\mathrm{n}=878093)\end{array}$ \\
\hline & \multirow{2}{*}{$\begin{array}{l}\text { B3: Sorted Suburbia } \\
\text { Households of mainly } 3 \text { to } 4 \text { people living in half or fully } \\
\text { paid western houses, located in urban areas. } \\
\text { Mainly middle-age English or Afrikans speaking } \\
\text { individuals with high education, low unemployment, and } \\
\text { high average household income. }\end{array}$} & $\begin{array}{l}\text { Jongens } \\
(n=357 \text { 152) }\end{array}$ \\
\hline & & $\begin{array}{l}\text { Highbrow } \\
(n=793310)\end{array}$ \\
\hline $\begin{array}{l}\text { Cluster C } \\
\text { Industrial - commercial - } \\
\text { conservation grounds, parklands } \\
\text { and open spaces. }\end{array}$ & No-Mans-Land & $\begin{array}{l}\text { No-Persons-Land } \\
(\mathrm{N}=515770)\end{array}$ \\
\hline
\end{tabular}




\section{Appendix B - Questionnaire/ Vraelys}

Please mark the relevant box with an $\mathrm{X}$ or write an explanation where necessary. / Merk asb. die relevante blokkie met 'n $\mathrm{X}$ of skryf 'n verduideliking waar nodig.

\section{Household / Huishouding}

[completed for primary participant in each household / voltooi vir hoofdelemer in elke huishouding]

(a) How many people live in this house? / Hoeveel mense bly in hierdie huis?

(b) How many people in this house are school-going age or younger? / Hoeveel mense in hierdie huis is van skoolgaan ouderdom of jonger?

(c) How many people in this house are out of school and unemployed/casual labour? / Hoeveel mense in hierdie huis is uit die skool uit en sonder werk/'n los werker?

(d) How many people in this house have full employment? / Hoeveel mense in hierdie huis het voltydse werk?

(e) How many people in this house are retired? / Hoeveel mense in hierdie huis is afgetree?

2. Individual participant / Individuele deelnemer

[completed for each participant / voltooi vir elke deelnemer]

(a) Age / Ouderdom

(b) Gender / Geslag

(c) Level of education / Graad van onderrig (e.g. std 3, grade 10, etc. / bv. std 3, graad 10, ens.)

\section{Language / Taal}

[completed for each adult participant / voltooi vir elke volwassene deelnemer]

(a) Which language do you regard as your first language? / Watter taal beskou jy as jou eerste taal?

$\square$ Afrikaans

$\square$ English/Engels

$\square$ Other/Ander

(b) What language do you use with your partner? Watter taal gebruik jy met jou eggenoot?

$\square$ Afrikaans

$\square$ English/Engels

$\square$ Other/Ander

(c) Which language(s) are used in close family interactions? / Watter taal/tale word gebruik tydens familie interaksies?

$\square$ Afrikaans

$\square$ English/Engels

$\square$ Other/Ander

(d) What was your language of schooling? / Wat was jou taal van onderrig?

$\square$ Afrikaans

$\square$ English/Engels

$\square$ Other/Ander

(e) Which language would you have preferred as your language of schooling? Watter taal sou jy verkies het as jou taal van onderrig?

$\square$ Afrikaans

$\square$ English/Engels

$\square$ Other/Ander 
(f) What language do you (did you) use when speaking to your parents? / Watter taal gebruik jy (het jy gebruik) wanneer jy met jou ouers praat?

$\square$ Afrikaans

$\square$ English/Engels

$\square$ Other/Ander

(g) Is your first language different from that of your parents? Het jy 'n ander eerste taal as jou ouers?

$\square \mathrm{Yes} / \mathrm{Ja}$

$\square \mathrm{No} / \mathrm{Nee}$

If No / Indien Nee:

(h) Whose choice was it? / Wie se keuse was dit?

If Yes / Indien Ja:

(i) Why did your parents want you to speak a different language? / Hoekom wou jou ouers hê dat jy 'n ander taal praat?

$\square$ (i) improve social mobility / verbeter sosiale vooruitgang

$\square$ (ii) improve employment opportunities / verbeter werksgeleenthede

$\square$ (iii) better schools and better educational opportunities / beter skole en beter opvoedingsgeleenthede

$\square$ (iv) Afrikaans is language of the former oppressive government (political reasons) / Afrikaans is die taal van die voormalige onderdrukkende regering (politieke redes)

$\square$ (v) Other/Ander

(j) Do you have children? Het jy kinders?

$\square \mathrm{Yes} / \mathrm{Ja}$

$\square \mathrm{No} / \mathrm{Nee}$

If Yes / Indien ja

(k) What language do you use when speaking to your child(ren)? / Watter taal gebruik jy wanneer jy met jou kind(ers) praat?

$\square$ Afrikaans

$\square$ English/Engels

$\square$ Other/Ander

(1) Is your first language different from that of your child(ren)? / Het jy 'n ander eerste taal as jou kind(ers)?

$\square \mathrm{Yes} / \mathrm{Ja}$

$\square \mathrm{No} / \mathrm{Nee}$

If No / Indien Nee:

(m) Whose choice was it? / Wie se keuse was dit?

If Yes / Indien Ja:

(n) Why did you want your children to speak a different language? / Hoekom wou jy gehad het jou kinders moes ' $n$ ander taal praat?

$\square$ (i) improve social mobility / verbeter sosiale vooruitgang

$\square$ (ii) improve employment opportunities / verbeter werksgeleenthede

$\square$ (iii) better schools and better educational opportunities / beter skole en beter opvoedingsgeleenthede

$\square$ (iv) Afrikaans is language of the former oppressive government (political reasons) / Afrikaans is die taal van die voormalige onderdrukkende regering (politieke redes)

$\square$ (v) Other/Ander 
(o) Which language would you prefer as their language of schooling? / Watter taal sal jy verkies as hulle taal van onderrig?

$\square$ Afrikaans

$\square$ English/Engels

$\square$ Other/Ander

(p) Why do you prefer this language as the language of schooling? / Hoekom verkies jy hierdie taal as 'n taal van onderrig?

$\square$ (i) improve social mobility/ verbeter sosiale vooruitgang

$\square$ (ii) improve employment opportunities/ verbeter werksgeleenthede

$\square$ (iii) better schools and better educational opportunities/ beter skole en beter opvoedingsgeleenthede

$\square$ (iv) Afrikaans is the language of the former oppressive government (political reasons)/ Afrikaans is die taal van die voormalige onderdrukkende regering (politieke redes)

$\square$ (v) Other/Ander

(q) What language do you use the most when talking to other people in the community? / Watter taal gebruik jy die meeste wanneer jy met ander mense in die gemeenskap praat?

$\square$ Afrikaans

$\square$ English/Engels

$\square$ Other/Ander

(r) If you go to church, what language(s) is/are used for church services? / Wanneer jy kerk toe gaan watter taal/tale word gebruik vir die kerkdienste?

$\square$ Afrikaans

$\square$ English/Engels

$\square$ Other/Ander

(s) Which language would you prefer for church services and why? / Watter taal sal jy verkeies vir kerkdienste en hoekom?

$\square$ Afrikaans

$\square$ English/Engels

$\square$ Other/Ander

(t) Which language(s) do you use at work? / Watter taal/tale gebruik jy by die werk?

$\square$ Afrikaans

$\square$ English/Engels

$\square$ Other/Ander

(u) Which language would you prefer to use when speaking to a co-worker? / Watter taal sal jy verkies om te gebruik wanneer jy met'n medewerker praat?

$\square$ Afrikaans

$\square$ English/Engels

$\square$ Other/Ander

(v) Do you find it valuable to know more than one language? Give a reasons for your answer / Vind jy dit waardevol om meer as een taal te ken? Gee 'n rede vir jou antwoord

$\square \mathrm{Yes} / \mathrm{Ja}$

$\square \mathrm{No} / \mathrm{Nee}$

(w) Do you find it difficult to use different languages at different times? Give reasons for your answer / Vind jy dit moeilik om verskillende tye verskillende tale te gebruik? Gee redes vir jou antwoord

$\square \mathrm{Yes} / \mathrm{Ja}$

$\square \mathrm{No} / \mathrm{Nee}$ 
(x) Specify your ability in each language using numbers as follows / Spesifiseer jou vermoë met betrekking tot elkeen van die gegewe tale deur die volgende nommers te gebruik:

$1=\operatorname{good} /$ goed

$2=$ fair $/$ redelik

$3=$ poor $/$ sleg

\begin{tabular}{|l|l|l|l|l|}
\hline & $\begin{array}{l}\text { Understand / } \\
\text { Verstaan }\end{array}$ & Speak / Praat & Read / Lees & Write / Skryf \\
\hline Afrikaans & & & & \\
\hline English & & & & \\
\hline Other / Ander & & & & \\
\hline & & & & \\
\hline
\end{tabular}

\section{Language / Taal}

[completed for each child participant / voltooi vir elke kind deelnemer]

(a) Which language do you regard as your first language? / Watter taal beskou jy as jou eerste taal?

$\square$ Afrikaans

$\square$ English/Engels

$\square$ Other/Ander

(b) What is your language of schooling? / Wat is jou taal van onderrig?

$\square$ Afrikaans

$\square$ English/Engels

$\square$ Other/Ander

(c) Which language do you prefer as your language of schooling? / Watter taal verkies jy as jou taal van onderrig?

$\square$ Afrikaans

$\square$ English/Engels

$\square$ Other/Ander

(d) Which language(s) are used in close family interactions? / Watter taal/tale word gebruik tydens familie interaksies?

$\square$ Afrikaans

$\square$ English/Engels

$\square$ Other/Ander

(e) What language do you use when speaking to your parents? / Watter taal gebruik jy wanneer jy met jou ouers praat?

$\square$ Afrikaans

$\square$ English/Engels

$\square$ Other/Ander

(f) Is your first language different from that of your parents? / Het jy 'n ander eerste taal as jou ouers?

$\square \mathrm{Yes} / \mathrm{Ja}$

$\square \mathrm{No} / \mathrm{Nee}$

If No / Indien Nee:

(g) Whose choice was it? / Wie se keuse was dit?

If Yes / Indien Ja:

(h) Why do your parents want you to speak English? / Hoekom wil jou ouers hê dat jy Engels praat?

$\square$ (i) improve social mobility / verbeter sosiale vooruitgang

$\square$ (ii) improve employment opportunities / verbeter werksgeleenthede

$\square$ (iii) better schools and better educational opportunities / beter skole en beter opvoedingsgeleenthede

$\square$ (iv) Afrikaans is language of the former oppressive government (political reasons) / Afrikaans is die taal van die voormalige onderdrukkende regering (politieke redes)

$\square(\mathrm{v})$ Other/Ander 
(i) What language do you use the most when talking to other people in the community? / Watter taal gebruik jy die meeste wanneer jy met ander mense in die gemeenskap praat?

$\square$ Afrikaans

$\square$ English/Engels

$\square$ Other/Ander

(j) If you go to church, what language(s) is/are used for church services? / Wanneer jy kerk toe gaan watter taal/tale word gebruik vir die kerkdienste?

$\square$ Afrikaans

$\square$ English/Engels

$\square$ Other/Ander

(k) Which language would you prefer for church services and why? / Watter taal sal jy verkeies vir kerkdienste en hoekom?

$\square$ Afrikaans

$\square$ English/Engels

$\square$ Other/Ander

(1) Do you find it valuable to know more than one language? Give a reason for your answer. / Vind jy dit waardevol om meer as een taal te ken? Gee 'n rede vir jou antwoord.

$\square \mathrm{Yes} / \mathrm{Ja}$

$\square \mathrm{No} / \mathrm{Nee}$

(m) Do you find it difficult to use different languages at different times? Give reasons for your answer. / Vind jy dit moeilik om verskillende tye verskillende tale te gebruik? Gee redes vir jou antwoord.

$\square \mathrm{Yes} / \mathrm{Ja}$

$\square \mathrm{No} / \mathrm{Nee}$

(n) Specify your ability in each language using numbers as follows / Spesifiseer jou vermoë met betrekking tot elkeen van die gegewe tale deur die volgende nommers te gebruik:

$1=$ good $/$ goed

2 = fair $/$ redelik

$3=$ poor $/$ sleg

\begin{tabular}{|l|l|l|l|l|}
\hline & $\begin{array}{l}\text { Understand / } \\
\text { Verstaan }\end{array}$ & Speak / Praat & Read / Lees & Write / Skryf \\
\hline Afrikaans & & & & \\
\hline English & & & & \\
\hline Other / Ander & & & & \\
\hline & & & & \\
\hline
\end{tabular}

